\title{
HAUS7 wt Allele
}

National Cancer Institute

\section{Source}

National Cancer Institute. HAUS7 wt Allele. NCI Thesaurus. Code C113688.

Human HAUS7 wild-type allele is located in the vicinity of Xq28 and is approximately $48 \mathrm{~kb}$ in length. This allele, which encodes HAUS augmin-like complex subunit 7 protein, plays a role in mitotic spindle assembly, centrosome integrity and cytokinesis. 